\title{
Influence of plant growth regulators and UV light exposure on the formation and phenolic content of Stevia rebaudiana Bertoni callus: A preliminary study
}

\author{
Florina O. Pacaldo ${ }^{1 *}$ and Catherine C. Arradaza ${ }^{2}$
}

This study was conducted to evaluate the effect of different combination and levels of plant growth regulators, 2,4-dichlorophenoxy acetic acid (2,4-D) and 6-benzylaminopurine (BAP), on callus induction of Stevia rebaudiana Bertoni leaf and internode explants, and the total phenolic content of Stevia callus as influenced by the length of exposure to ultraviolet (UV) light radiation. Early callus initiation was recorded in leaf explants inoculated in Murashige and Skoog (MS) medium supplemented with 2,4-D and BAP. After a week of incubation, leaf explants showed callus formation while in internode explants, callus formation was observed 2 weeks after inoculation. The culture medium supplemented with $1.5 \mathrm{mg} \mathrm{L}^{-1} 2,4-\mathrm{D}+2.0 \mathrm{mg} \mathrm{L}^{-1} B A P\left(\mathrm{~T}_{4}\right)$ was the best treatment for leaf explants with $95 \%$ callus formation and the addition of $1.0 \mathrm{mg} \mathrm{L}^{-1} 2,4-\mathrm{D}+$ 4.0mg L $\mathrm{L}^{-1} \mathrm{BAP}\left(\mathrm{T}_{3}\right)$ was the best treatment for internode explant with $90 \%$ callus formation. After 4 weeks of incubation, the leaf and internode calli were observed as compact, non-embryogenic, and yellowish green in all treatments except those inoculated in MS medium alone (control). Stevia leaf callus was subjected to UV radiation after 4 weeks at varying time of exposure. The exposed calli turned brown signifying a possible increasing production of secondary metabolites. Furthermore, combination of $1.5 \mathrm{mg} \mathrm{L}^{-1} 2,4-\mathrm{D}+2.0 \mathrm{mg} \mathrm{L}^{-1}$ $\operatorname{BAP}\left(\mathrm{T}_{4}\right)$ and $3 \mathrm{~h}$ of UV light exposure yielded the highest phenolic content of $87.71 \mathrm{mg}$ GAE per $\mathrm{g}$ callus. The results further revealed that both medium composition and time of exposure affect the production of phenolic content of Stevia leaf callus.

Keywords: Stevia rebaudiana Bertoni, Phenolic Content, UV light exposure, Callus

'Department of Biotechnology, College of Arts and Sciences, Visayas State University, Baybay City, Leyte 6521-A Philippines

2Department of Horticulture, Visayas State University, Baybay City, Leyte 6521-A

*Corresponding Author. Address: Department of Biotechnology, College of Arts and Sciences, Visayas State
University, Baybay City, Leyte6521-APhilippines; Email:pacaldoflorina@gmail.com

(C) Visayas State University, Baybay City, Leyte, Philippines 


\section{INTRODUCTION}

Stevia rebaudiana Bertoni or Stevia is a perennial herb of Asteraceae family and is commonly known as the "sweet leaf", "sugar leaf" or "candy leaf". Stevia is native in Paraguay and Brazil but is also widely grown in the South America and East Asia due to its natural sweet content. It is a sweetener of drinks, of various foods, and of traditional medicines -- the reason why it was called as the "sweet herb of Paraguay". The natural sweet properties of Stevia are characterized by the chemical component of diterpene glycoside which includes primarily the stevioside, steviolside, dulcoside and rebaudioside A to E (Gupta et al 2013). Almost all parts of the plant have the sweet taste; however, the sweet glycosides are typically concentrated in the green serrated leaves. Steviol glycosides, stevioside and rebaudiana $A$, are the most abundant chemical compounds that can be found in the Stevia leaves. These compounds are 300 times sweeter than the cane sugar (Goyal and Goyal 2010), Basically, these metabolized compounds leave the body without accumulation. Other than its value as sweeteners, Stevia and its glycosides have pharmacological effects against several diseases such as cancer, diabetes mellitus, hypertension, inflammation, cystic fibrosis, obesity, and tooth decay. Several studies have shown that steviol glycosides found in Stevia are not teratogenic, mutagenic or carcinogenic and cause no acute and subacute toxicity (Huang et al 2009). In addition, Stevia had shown antioxidant activity due its high content of phenolic compound compared to the other plant (Shukla et al 2009).

According to the US Food and Drug Administration in December 2008, FDA issued a letter declaring Stevia plant extract as generally recognized as safe (GRAS) for use in beverages, foods and sweeteners, and allowed its use in US food production. There is an increasing demand for phenolic compounds and other bioactive compounds of Stevia as important constituents for human diet and high potential therapeutic effects.

Recently, Stevia is one of the plants that is domesticated due to its high medicinal and commercial value; therefore, it is necessary to cultivate it for commercial purposes. However, the propagation of Stevia is laborious since the seed germination percentage is very low due to its self incompatibility, and its insect pollinated clear seeds are infertile (Debnath 2008, Raina et al 2013). The vegetative propagation is limited also since it has a low number of planting material that can be obtained in a single plant. As a result, it is difficult to reach the commercial quantities needed in the market. To address this problem, tissue culture technique is developed to produce large number of plant materials in a very short period of time for commercial purposes. In addition, the advanced propagation technique of Stevia to generate a higher level of steviol glycoside (Gupta et al 2010) and other valuable compounds of Stevia especially the phenolic compounds is being done. Several studies reported that Stevia plant parts such as leaves, nodes, and shoot tips can be used to raise plants in vitro (Naz and Hashmi 2008). In a similar study using a suspension culture, embryogenesis was achieved and the level of stevioside content was increased due to the addition of ammonium nitrate (Sharma et al 2015).

There are several reported methods to enhance the production of secondary metabolites. One of these methods is the UV light exposure which acts as an abiotic stress that can affect the physiological processes and morphology of the Stevia 
and at the same time produce secondary metabolites as defense mechanism and adaptation to the stressful environmental condition.

The study aimed to evaluate the responses of Stevia leaves and internodes as explants to different combinations and levels of 2,4-dichlorophenoxy acetic acid (2,4-D) and 6-benzylaminopurine (BAP) on callus induction; establish the appropriate levels of 2-4 D and BAP for callus induction; and to determine the total phenolic content of Stevia callus as influenced by the length of exposure to ultraviolet (UV) light radiation.

\section{MATERIALS AND METHODS}

\section{Collection of Plant Materials}

The sources of the explants were obtained directly from a Stevia plant grown in the Ornamental Area of the Department of Horticulture, College of Agriculture and Food Science, Visayas State University, ViSCA, Baybay City, Leyte, Philippines. The mother plant was then transferred into the screen house for maintenance. The mother plant was pretreated with fungicide (Dithane) once-a-day for three (3) days prior to preparation of explants.

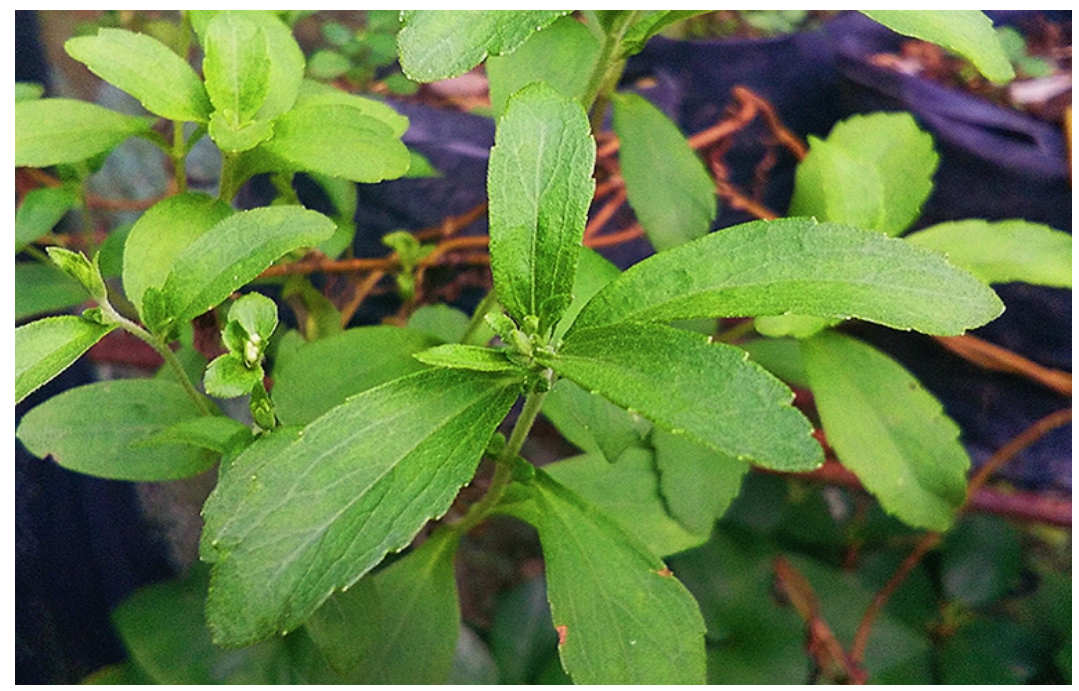

Figure 1. Stevia plant

\section{Preparation of Leaf and Internode Explants}

The freshly collected Stevia leaves and internodes were washed with liquid soap under running tap water and wiped dry with cotton. A $70 \%$ ethanol was used to clean the explants and to remove the trichomes where the contaminants were attached. Then, it was treated in $20 \%$ commercial bleach solution and decanted after 5 mins of manual agitation. Finally, all explants were immersed in with $20 \%$ commercial bleach solution for further surface sterilization for $5 \mathrm{mins}$ inside the 
Influence of plant growth regulators and UV light exposure

laminar flow hood before rinsing thoroughly with sterilized distilled water three times. The leaves and internodes of Stevia were excised aseptically using a sterilized scalpel measuring $5 \mathrm{~mm}$ for leaf explant and $10 \mathrm{~mm}$ long for internode explants and inoculated in the sterilized culture vessels.

\section{Culture Medium Preparation}

All explants were cultured in a Murashige and Skoog (MS 1962) medium supplemented with $30 \mathrm{~g} \mathrm{~L}^{-1}$ of sucrose and $5 \mathrm{~g} \mathrm{~L}^{-1}$ of agar with the addition of different concentrations and combinations of plant growth regulators such as 2,4dichlorophenoxy acetic acid (2,4-D) and benzylaminopurine (BAP). The $\mathrm{pH}$ was adjusted to 5.8 using $1.0 \mathrm{~N} \mathrm{HCl}$ or $1.0 \mathrm{~N} \mathrm{NaOH}$ prior to dispensing. The culture vessels containing $10 \mathrm{~mL}$ of medium treatment were sterilized by autoclaving at $121^{\circ} \mathrm{C}$ at a pressure of $15 \mathrm{psi}$ for $20 \mathrm{~min}$. Cultures were incubated for 4 weeks at $25 \pm 2^{\circ} \mathrm{C}$, under cool white fluorescent light having 2500 lux light intensity in an $8 \mathrm{~h}$ light and $16 \mathrm{~h}$ dark light cycle.

\section{UV Light Exposure}

After four weeks of culture incubation, the Stevia calli were exposed to UV radiation inside the laboratory using the laminar flow hood UV (UV-B) with exposure time of 1,3 , and 5 h, for 4 days (Table 1 ). Each culture was placed diagonally for complete exposure of the callus to UV rays.

Table 1. Length of UV Light Exposure

\begin{tabular}{cc}
\hline Factor 1 & $\begin{array}{c}\text { Lengt hof ExposuretolVI } \\
\text { (Hour per day) }\end{array}$ \\
\hline$E_{0}$ & ight \\
$E_{1}$ & Control (no exposure) \\
$E_{2}$ & 1 \\
$E_{3}$ & 3 \\
\hline
\end{tabular}

\section{Preparation of the Callus Extract}

After the Stevia calli were exposed to UV radiation, the control and the irradiated calli were then collected from the medium using forceps and weighed using analytical balance. One gram callus for each treatment was macerated and transferred to a tube with cover and added with $3 \mathrm{~mL}$ pure methanol and incubated at room temperature for $24 \mathrm{~h}$ free from light for complete extraction. The extract was filtered using the filter paper and $1 \mathrm{~mL}$ of the filtrate was obtained and placed in the tube with cover and stored at $4^{\circ} \mathrm{C}$ for further analysis.

\section{Determination of Total Phenols}

Folin-Ciocalteu assay method was used for the determination of the total phenolic content (Kaur and Kapoor 2002). Gallic acid was used as standard. The reaction mixture consisted of $1 \mathrm{~mL}$ of plant extract added with $5 \mathrm{~mL}$ distilled 
water, then mixed thoroughly with $0.5 \mathrm{~mL}$ of Folin-Ciocalteu (1:10) reagent (Scharlau, Scharlab S.L.). After $5 \mathrm{~min}, 1.5 \mathrm{~mL}$ of $20 \%$ sodium carbonate solution was added and was allowed to stand for $60 \mathrm{mins}$. The sample was measured at $650 \mathrm{~nm}$ using UV-Vis Spectrophotometer (Shimadzu UV-1800) and the total phenolic content was calculated from the calibration curve and expressed as mg gallic acid per $\mathrm{g}$ of callus weight.

\section{Treatments, Experimental Design and Statistical Analysis}

The experiment was laid out in a 2-Factor Factorial Experiment in Completely Randomized Design (CRD) with three replicates per treatment and ten sample cultures per replicate (Table 2). The obtained data on total phenolic content was subjected to analysis of variance (ANOVA) to determine the significant differences among treatment combinations of UV light exposure and medium composition. Multiple comparison procedure was done with the use of the Tukey's Honest Significant Difference (HSD) Test for differences between means at $5 \%$ level of significance.

Table 2. Media Treatments for callus induction using leaf and internode explants of Stevia rebaudiana Bertoni

\begin{tabular}{cl}
\hline Factor 2 & \multicolumn{1}{c}{ Medium Composition } \\
\hline (Treatment Code) & MS alone \\
\hline $\mathrm{T}_{0}$ & $\mathrm{MS}+1.0 \mathrm{mg} \mathrm{L}^{-1} 2,4-\mathrm{D}+2.0 \mathrm{mg} \mathrm{L}^{-1} \mathrm{BAP}$ \\
$\mathrm{T}_{1}$ & $\mathrm{MS}+1.0 \mathrm{mg} \mathrm{L}^{-1} 2,4-\mathrm{D}+3.0 \mathrm{mg} \mathrm{L}^{-1} \mathrm{BAP}$ \\
$\mathrm{T}_{2}$ & $\mathrm{MS}+1.0 \mathrm{mg} \mathrm{L}^{-1} 2,4-\mathrm{D}+4.0 \mathrm{mg} \mathrm{L}^{-1} \mathrm{BAP}$ \\
$\mathrm{T}_{3}$ & $\mathrm{MS}+1.5 \mathrm{mg} \mathrm{L}^{-1} 2,4-\mathrm{D}+2.0 \mathrm{mg} \mathrm{L}^{-1} \mathrm{BAP}$ \\
$\mathrm{T}_{4}$ & $\mathrm{MS}+1.5 \mathrm{mg} \mathrm{L}^{-1} 2,4-\mathrm{D}+3.0 \mathrm{mg} \mathrm{L}^{-1} \mathrm{BAP}$ \\
$\mathrm{T}_{5}$ & $\mathrm{MS}+1.5 \mathrm{mg} \mathrm{L}^{-1} 2,4-\mathrm{D}+4.0 \mathrm{mg} \mathrm{L}^{-1} \mathrm{BAP}$ \\
\hline $\mathrm{T}_{6}$ &
\end{tabular}

*MS, Murashige and Skoog (1962) ; 2,4-D, 2,4-dichlorophenoxy acetic acid); BAP, 6-benzylaminopurine

\section{RESULTS AND DISCUSSION}

Effects of Different Combination and Levels of BAP and 2, 4-D on Callus Induction of Stevia Leaf and Internode Explants

An intermediation ratio of auxin and cytokinin have been widely used to generate callus (Ikeuchi et al 2013), and several studies reported that different explants have the ability to produce unorganized cells or to form into a new regenerated plant using different combinations of phytohormones (Pawar et al 2015). In the present study, it was found out that stevia leaf and internode explants have different responses to different combination and concentration of 2,4-D and BAP after 4 weeks of incubation (Figure 2). 

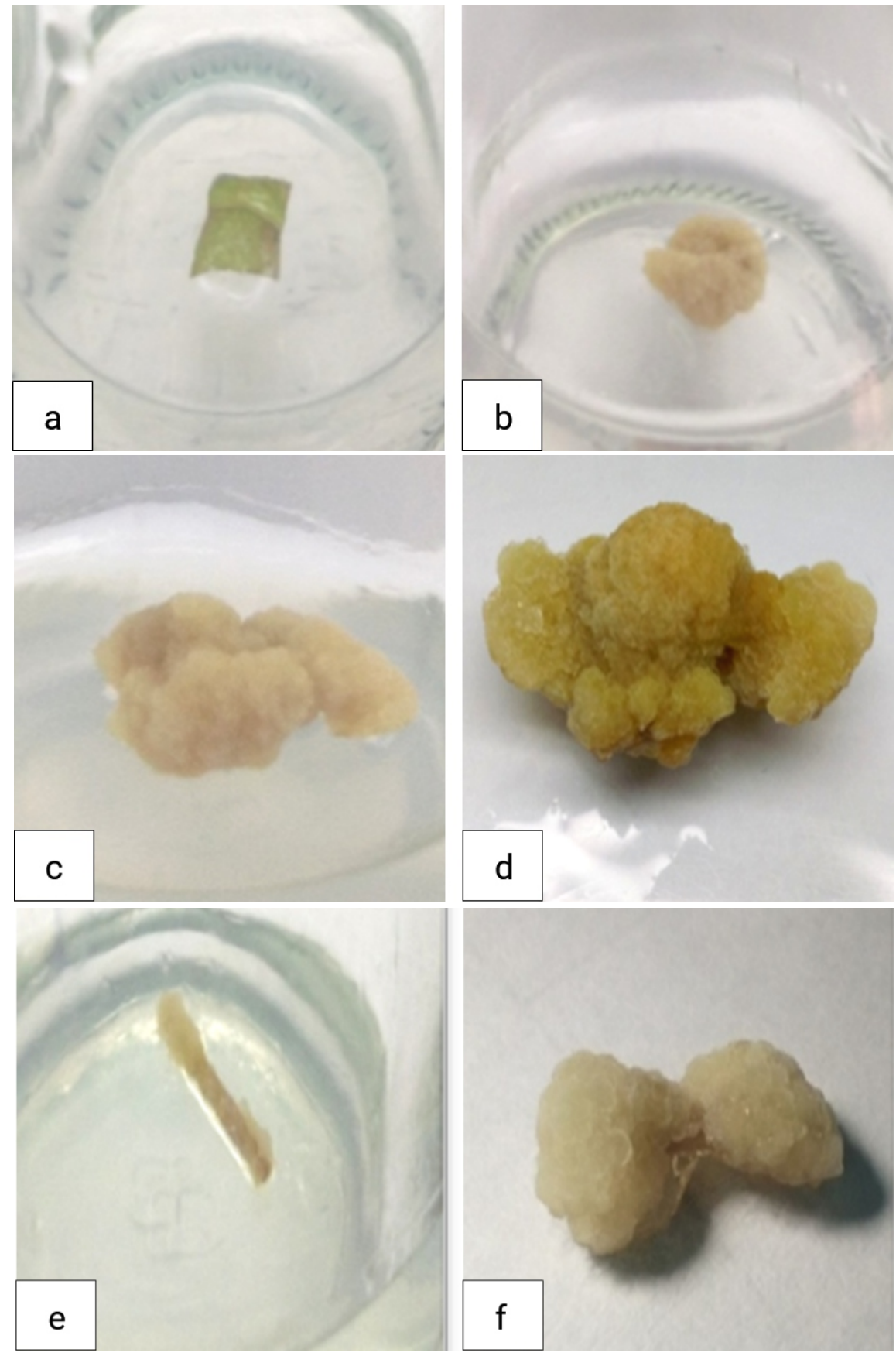

Figure 2. Responses of leaf and internode explants inoculated to MS medium supplemented with different combination and level of BAP and 2,4-D after 4 week incubation: (a-d) leaf explants at (a) 5 days, (b) 2 weeks, (c) 3 weeks and (d) 4 weeks of incubation, (e-g) internode explants at (e) 2 weeks, (f) 3 weeks and (g) 4 weeks of incubation. 


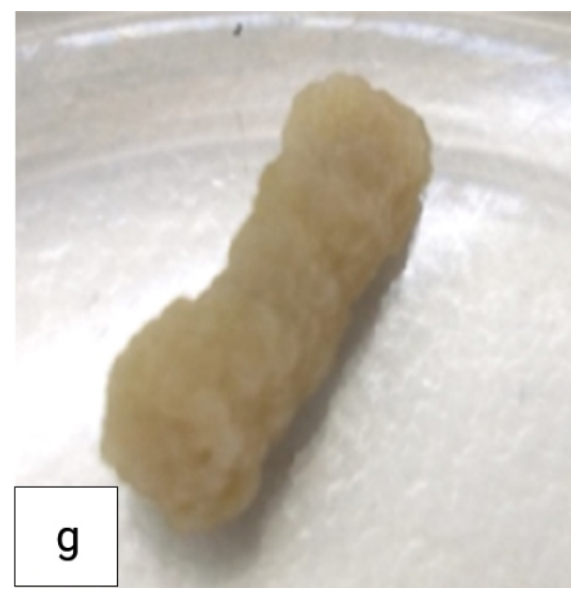

Figure 2. continued

\section{Stevia Callus Formation}

Callus formation is observed in response to stresses such as wounding or pathogen infection as well as the different concentration and combination of plant growth regulators. In addition, different explants have also different responses to the formation of callus (lkeuchi et al 2013). The callus initiation was observed in both explants but was first observed in the cut margin of the leaf explants in culture medium supplemented with BAP and 2,4-D. Earliest period (11 days) of callus formation for leaf explants was observed in MS medium supplemented with $1.5 \mathrm{mg} \mathrm{L}^{-1}$ 2,4-D + 3.0 $\mathrm{mg} \mathrm{L}^{-1} \mathrm{BAP}\left(\mathrm{T}_{5}\right)$, while the longest callus induction (15 days) was observed in 1.0 $\mathrm{mg} \mathrm{L}^{-1} 2,4-\mathrm{D}+3.0 \mathrm{mg} \mathrm{L}^{-1} \mathrm{BAP}\left(\mathrm{T}_{2}\right)$ (Figure 4). Meanwhile in internode explants, early callus formation (16 days) was observed in MS culture medium added with $1.0 \mathrm{mg} \mathrm{L}^{-1}$ 2,4-D + 4.0mg $\mathrm{L}^{-1}$ BAP $\left(\mathrm{T}_{3}\right)$ while the longest period of response (20 days) was observed in 1.5 $\mathrm{mg} \mathrm{L}^{-1} 2,4-\mathrm{D}+2.0 \mathrm{mg} \mathrm{L}^{-1} \mathrm{BAP}\left(\mathrm{T}_{4}\right)$ (Figure 3).

A week after inoculation, $M S+1.5 \mathrm{mg} \mathrm{L}^{-1} 2,4-\mathrm{D}+3.0 \mathrm{mg} \mathrm{L}^{-1} \mathrm{BAP}\left(\mathrm{T}_{5}\right)$ had the highest percentage of callus formation (34.78\%) in leaf explants (Table 3 ). Mean percentage of callus formation after four weeks showed no significant difference among treatments with different levels of 2,4D and BAP. The result suggests that any of the treatment levels can be used for callus induction of stevia. Likewise, among all culture medium that was used, $M S+1.5 \mathrm{mg} \mathrm{L}^{-1} 2,4-\mathrm{D}+2.0 \mathrm{mg} \mathrm{L}^{-1} \mathrm{BAP}(95.24 \%)$ in leaf explants and $M S+1.0 \mathrm{mg} \mathrm{L}^{-1} 2,4-\mathrm{D}+4.0$ BAP $\mathrm{mg} \mathrm{L}^{-1}(90 \%)$ in internode explants showed the highest percentage of callus formation while MS alone did not formcallus.

In the present study, both leaf and internode explants exhibited callus formation cultured on MS medium supplemented with 2,4-D and BAP. However, leaf explants formed callus earlier than the internode, but after 2 weeks of incubation callus formation was exhibited in all treatments except control and in culture medium with $\mathrm{MS}+1.5 \mathrm{mg} \mathrm{L}^{-1} 2,4-\mathrm{D}+2.0 \mathrm{mg} \mathrm{L}^{-1} \mathrm{BAP}\left(\mathrm{T}_{4}\right)$. This result signifies that leaf explants have more meristematic region which is composed of active cells that has the potential to respond immediately to suitable medium for callus induction compared to the internode explants (Ikeuchi et al 2013). 


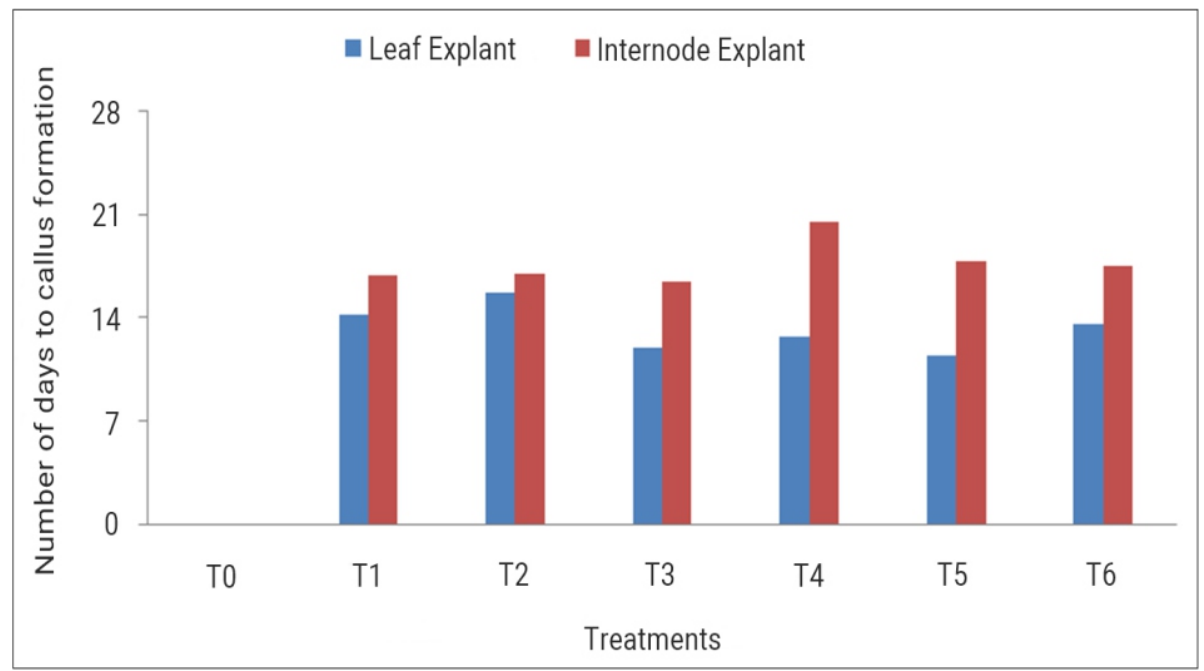

Figure 3. Number of days to callus formation in leaf and internode explants inoculated in MS medium supplemented with different combination and level of 2,4-D and BAP.

Treatments:

$\mathrm{T}_{0}$ MS alone

$\mathrm{T}_{1} \cdot \mathrm{MS}+1.0 \mathrm{mg} \mathrm{L}^{-1} 2,4-\mathrm{D}+2 \mathrm{mg} \mathrm{L}^{-1} \mathrm{BAP}$

$\mathrm{T}_{4} \mathrm{MS}+1.5 \mathrm{mg} \mathrm{L}^{-1} 2,4-\mathrm{D}+2 \mathrm{mg} \mathrm{L}^{-1} \mathrm{BAP}$

$\mathrm{T}_{2} \mathrm{MS}+1.0 \mathrm{mg} \mathrm{L}^{-1} 2,4-\mathrm{D}+3 \mathrm{mg} \mathrm{L}^{-1} \mathrm{BAP}$

$\mathrm{T}_{5} \mathrm{MS}+1.5 \mathrm{mg} \mathrm{L}^{-1} 2,4-\mathrm{D}+3 \mathrm{mg} \mathrm{L}^{-1} \mathrm{BAP}$

$\mathrm{T}_{3} \mathrm{MS}+1.0 \mathrm{mg} \mathrm{L}^{-1} 2,4-\mathrm{D}+4 \mathrm{mg} \mathrm{L}^{-1} \mathrm{BAP}$

$\mathrm{T}_{6} \mathrm{MS}+1.5 \mathrm{mg} \mathrm{L}^{-1} 2,4-\mathrm{D}+4 \mathrm{mg} \mathrm{L}^{-1} \mathrm{BAP}$

Table 3. Percentage of callus formation in leaf and internode explants of Stevia rebaudiana Bertoni inoculated to MS medium supplemented with 2,4-D and BAP after 4 weeks from inoculation

\begin{tabular}{|c|c|c|c|c|c|c|}
\hline \multirow[b]{2}{*}{$\begin{array}{l}\text { Treatment } \\
\text { code }\end{array}$} & \multirow[b]{2}{*}{ Medium Composition } & \multicolumn{3}{|c|}{ Percentage Callus Formation } & \multirow[b]{2}{*}{$\begin{array}{c}\text { 4th } \\
\text { week }\end{array}$} & \multirow[b]{2}{*}{ Mean \pm SE } \\
\hline & & $\begin{array}{c}\text { 1st } \\
\text { week }\end{array}$ & $\begin{array}{r}\text { 2nd } \\
\text { week }\end{array}$ & $\begin{array}{r}\text { 3rd } \\
\text { week }\end{array}$ & & \\
\hline \multicolumn{7}{|l|}{ Leaf Explant } \\
\hline $\mathrm{T}_{0}$ & MSalone & 0 & 0 & 0 & 0 & $0.00^{\mathrm{a}} \pm 0$ \\
\hline $\mathrm{T}_{1}$ & $\mathrm{MS}+1.0 \mathrm{mgL}^{-1} 2,4-\mathrm{D}+20 \mathrm{BAP} \mathrm{mg} \quad{ }^{-1}$ & 16.00 & 52.00 & 68.00 & 92.00 & $9259^{b} \pm 3.70$ \\
\hline $\mathrm{T}_{2}$ & $\mathrm{MS}+1.0 \mathrm{mgL}^{-1} 2,4-\mathrm{D}+3.0 \mathrm{BAP} \mathrm{mg}$ & 10.71 & 4286 & 64.29 & 89.29 & $89.63^{b} \pm 5.79$ \\
\hline $\mathrm{T}_{3}$ & $\mathrm{MS}+1.0 \mathrm{mgL}^{-1} 2,4-\mathrm{D}+4.0 \mathrm{BAP} \mathrm{mg}$ & 9.09 & 59.09 & 81.82 & 81.82 & $83.33^{b} \pm 16.67$ \\
\hline $\mathrm{T}_{4}$ & $M S+1.5 \mathrm{mg} \mathrm{L}^{-1} 2,4-\mathrm{D}+20 \mathrm{BAP} \mathrm{mg}$ & 23.81 & 61.9 & 80.95 & 95.24 & $95.24{ }^{b} \pm 4.76$ \\
\hline $\mathrm{T}_{5}$ & $\mathrm{MS}+1.5 \mathrm{mgL}^{-1} 2,4-\mathrm{D}+3.0 \mathrm{BAP} \mathrm{mg}$ & 34.78 & 65.22 & 91.3 & 86.96 & $89.81^{b} \pm 4.76$ \\
\hline $\mathrm{T}_{6}$ & $\mathrm{MS}+1.5 \mathrm{mgL}^{-1} 2,4-\mathrm{D}+4.0 \mathrm{BAP} \mathrm{mg}$ & 12.00 & 52.00 & 72.00 & 88.00 & $89.76^{b} \pm 1235$ \\
\hline \multicolumn{7}{|c|}{ Inter node Explant } \\
\hline $\mathrm{T}_{0}$ & MSalone & 0 & 0 & 0 & 0 & $0.00{ }^{a} \pm 0$ \\
\hline $\mathrm{T}_{1}$ & $\mathrm{MS}+1.0 \mathrm{mgL}^{-1} 2,4-\mathrm{D}+20 \mathrm{BAP} \mathrm{mL}^{-1}$ & 0 & 17. 24 & 6207 & 8276 & $83.33^{b} \pm 8.82$ \\
\hline $\mathrm{T}_{2}$ & $\mathrm{MS}+1.0 \mathrm{mgL}^{-1} 2,4-\mathrm{D}+3.0 \mathrm{BAP} \mathrm{mg} \quad-1$ & 0 & 10.00 & 76.67 & 83.33 & $83.33^{b} \pm 3.33$ \\
\hline $\mathrm{T}_{3}$ & $\mathrm{MS}+1.0 \mathrm{mgL}^{-1} 2,4-\mathrm{D}+4.0 \mathrm{BAPm} \mathrm{gL}^{-1}$ & 0 & 26.67 & 83.33 & 90.00 & $90.00{ }^{b} \pm 5.77$ \\
\hline $\mathrm{T}_{4}$ & $\mathrm{MS}+1.5 \mathrm{mgL}^{-1} 2,4-\mathrm{D}+20 \mathrm{BAP} \mathrm{mL}^{-1}$ & 0 & 0 & 40.00 & 86.67 & $86.67^{b} \pm 3.33$ \\
\hline $\mathrm{T}_{5}$ & $\mathrm{MS}+1.5 \mathrm{mg} \mathrm{L}^{-1} 2,4-\mathrm{D}+3.0 \mathrm{BAP} \mathrm{mg} \mathrm{L}_{-1}^{-1}$ & 0 & 20.00 & 70.00 & 86.67 & $86.67^{b} \pm 8.82$ \\
\hline $\mathrm{T}_{6}$ & $\mathrm{MS}+1.5 \mathrm{mgL}^{-1} 2,4-\mathrm{D}+4.0 \mathrm{BAP} \mathrm{mg}$ & 0 & 3.33 & 60.00 & 80.00 & $80.00^{b} \pm 5.77$ \\
\hline
\end{tabular}

* Results presented as mean \pm standard deviation

*Means sharing a letter in the group label are not significantly different at the $5 \%$ level of significance. 


\section{Description of Stevia Callus}

After 4 weeks of incubation, the leaf and internode callus appeared as compact, non-embryogenic, and yellowish green calli in all treatments (Figure 4, Table 4). Swelling was first observed in all treatments after one week from inoculation of all explants. However, in leaf explants, callus formation continued in the following weeks in all treatments unlike the internode explants. The cultures inoculated in MS alone turned brown in the succeeding weeks and eventually failed to initiate callus until termination
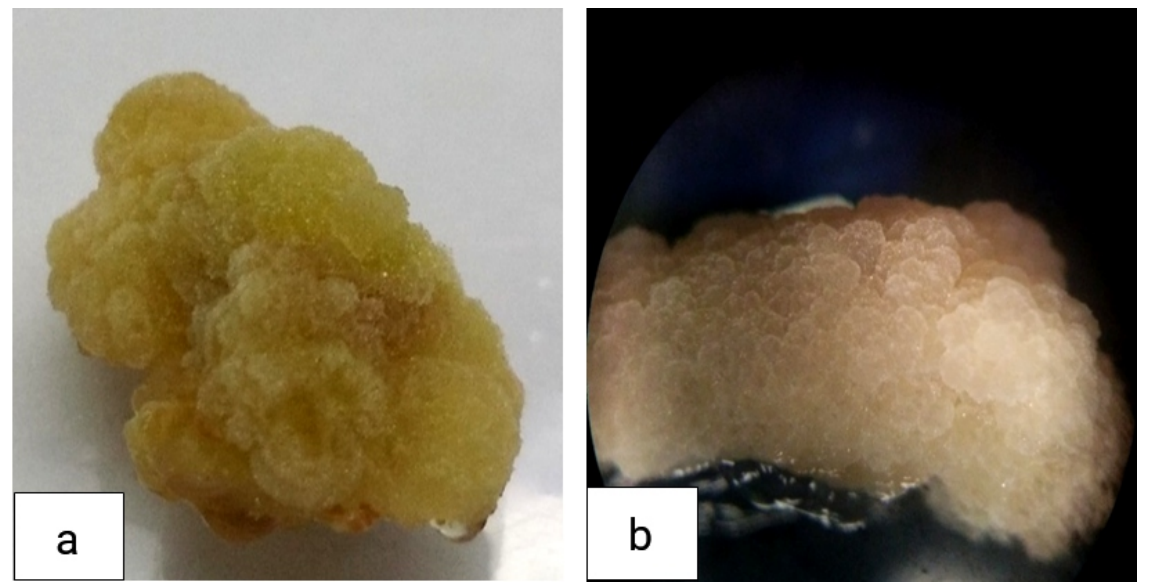

Figure 4. Stevia Callus from leaf explants (a) was compact, non-embryogenic, yellowish green and (b) light yellowish white callus in internode explants.

Stevia leaf and internode callus formed was rated following the scoring system used by Gurel et al (2001). The leaf callus obtained an average rate of 4 , which indicated a measurement greater than $10 \mathrm{~mm}$ callus form all the cultures in each treatment. However, in internode callus, a range of $5-10 \mathrm{~mm}$ or greater than $10 \mathrm{~mm}$ callus formation was recorded in all culture of each treatment. No rating was indicated in the control since no callus formation was observed after the explants bulged or swelled. Furthermore, the statistical analysis for callus weight both in leaf and internode explants was significantly different. Callus weight was highest at MS + 1.5 $\mathrm{mg} \mathrm{L}^{-1} 2,4-\mathrm{D}+3.0 \mathrm{mg} \mathrm{L}^{-1} \mathrm{BAP}\left(\mathrm{T}_{5}\right)$ in both type of explants. The leaf explants had the highest callus weight average of $0.54 \mathrm{~g}$ compared to internode explants which has $0.10 \mathrm{~g}$. This result signifies that, the culture medium supplemented with higher level of 2,4-D and BAP obtained a greater callus weight both in leaf and internode explant (Table 4).

The same study of Gupta et al 2010, reported that leaf segments can be the best explant for callus production of Stevia. A similar study also reported that stevia leaf and nodes explants cultured MS supplemented with 2,4-D or NAA in combination with $2.22 \mu \mathrm{M}$ BAP were effective. However, 2,4-D generated a higher frequencies of callus formation than NAA with $80 \%$ (leaf) and $60 \%$ (nodes) successful callus formation (Janarthanam et al 2009). In addition, indirect organogenesis of Cucumis anguria L. using the leaf and nodal explants, 
it was found out that leaf explants showed maximum response in culture medium supplemented with $4.0 \mathrm{mg} \mathrm{L}^{-1} \mathrm{NAA}$ and $4.0 \mathrm{mg} \mathrm{L}^{-1}$ 2,4-D compared to auxin and cytokinin alone (Jeyakumar, Vivekanandan 2015).

Table 4. Type and color of callus formed from leaf and internode explants grown in MS medium supplemented with 2,4-D and BAP after 4 weeks of incubation.

\begin{tabular}{|c|c|c|c|}
\hline $\begin{array}{l}\text { Treatment } \\
\text { Code }\end{array}$ & $\begin{array}{l}\text { Call us Weight } \\
\text { Mean }\end{array}$ & $\begin{array}{l}\text { Rate of } \\
\text { Callu } \mathrm{S}\end{array}$ & Callus Description \\
\hline \multicolumn{4}{|c|}{ Leaf Expl ant } \\
\hline $\mathrm{T}_{0}$ & $0.00^{b} \pm 0$ & 0 & Brown Explants/ Dead \\
\hline $\mathrm{T}_{1}$ & 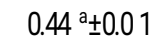 & 4 & compact, non -embryogenic, light yellowish green callus \\
\hline $\mathrm{T}_{2}$ & $0.47^{a} \pm 0.07$ & 4 & compact, no n-embryogenic, yellowish green callus \\
\hline $\mathrm{T}_{3}$ & $0.38^{a} \pm 0.03$ & 4 & compact, non -embryogenic, y ellowish white callus \\
\hline $\mathrm{T}_{4}$ & $0.40 \pm 0.03$ & 4 & compact, non -embryogenic, yellowish green callus \\
\hline$T_{5}$ & $0.54^{a} \pm 0.09$ & 4 & compact, non -embryogenic, yellowish white callus \\
\hline $\mathrm{T}_{6}$ & $0.26^{\mathrm{ab}} \pm 0.03$ & 4 & compact, non -embryogenic, yellowish white callus \\
\hline \multicolumn{4}{|c|}{ Intern ode explants } \\
\hline $\mathrm{T}_{0}$ & $0.00^{c} \pm 0$ & 0 & Brown Explants/ Dead \\
\hline $\mathrm{T}_{1}$ & $0.04^{b} \pm 0.01$ & 4 & compact, no n-embryogenic, light yellowish white callus \\
\hline $\mathrm{T}_{2}$ & $0.05^{b} \pm 0.00$ & 3 & compact, non -embryogenic, yellowish white callu \\
\hline $\mathrm{T}_{3}$ & $0.06^{b} \pm 0.01$ & 4 & compact, non -embryogenic, yellowish white callus \\
\hline $\mathrm{T}_{4}$ & $0.06^{b} \pm 0.00$ & 3 & compact, no n-embryogenic, yellowish white callus \\
\hline$T_{5}$ & $0.10^{a} \pm 0.00$ & 3 & compact, non -embryogenic, yellowish white callus \\
\hline $\mathrm{T}_{6}$ & $0.05^{b} \pm 0.01$ & 3 & compact, non -embryogenic, yello wish white callus \\
\hline
\end{tabular}

* Results presented as mean \pm standard deviation

*Means sharing a letter in the group label are not significantly different at the $5 \%$ level of significance

*Rate of callus: A '0-4 scale' scoring system developed for rating of callus, wherein 0 (No visible callus); 1 (Small proliferation at cut ends only); 2 ( $5 \mathrm{~mm}$ callus at cut ends); 3 ( $5-10 \mathrm{~mm}$ callus from all over the explants); 4 (>10mm callus from all over the explants)

\section{Total Phenolic Content of Stevia Calli}

When cultures were subjected to UV radiaton, Stevia leaf callus was observed to have affected color of calli. Irradiated calli produced brownish color all over the callus tissue (Figure 5), which may indicate that the irradiated calli have experienced abiotic stress through the UV radiation exposure and resulted to the production of secondary metabolites, specifically the phenolic compounds.

Phytochemical compounds that are present in different plant material can be obtained by milling, grinding, homogenization, and solvent extraction. Among all these steps, solvent extraction method is the best method that has always been used in recovering phytochemical compounds. The effectiveness of the extraction method depends on the solvent used, composition of phytochemical compounds, and also the presence of other interfering substances in the plant materials. The production yield of compounds in solvent extraction will depend also on the condition, $\mathrm{pH}$, temperature, extraction time and the polarity of the solvent used (Do et al 2013). 


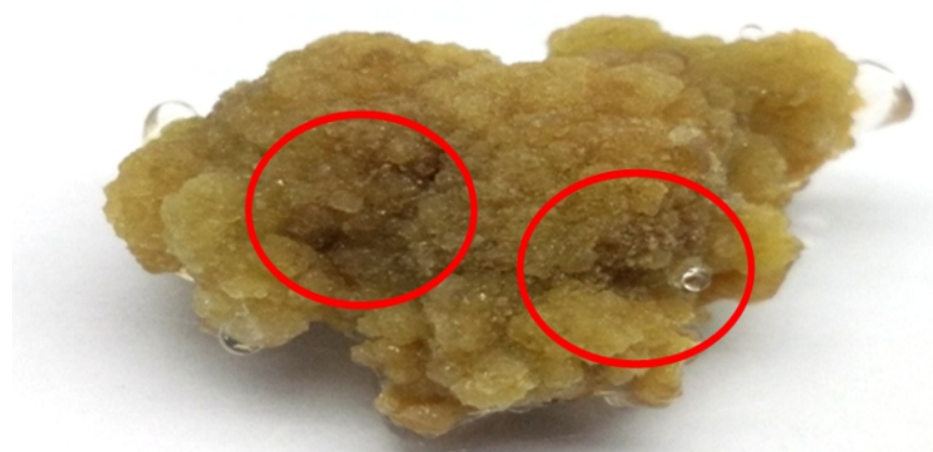

Figure 5. UV Irradiated calli derived Stevia leaf explants grown in $M S+1.5 \mathrm{mg} \mathrm{L}^{-1} 2,4-\mathrm{D}+2 \mathrm{mg} \mathrm{L}^{-1}$ $\operatorname{BAP}\left(\mathrm{T}_{4}\right)$ after $3 \mathrm{~h}$ of exposure, showing brown callus tissues.

In this study, a quantitative analysis was conducted to determine the total phenolic content of UV irradiated stevia leaf callus with different time of exposure. The stevia leaf callus extract was obtained with the use of pure methanol as solvent. Methanol is colorless and volatile that is used in organic synthesis, fuel, antifreeze and as solvent. Methanol as an extraction solvent is very popular due to its high polarity that can dissociate the hydroxyl group and reported as more efficient in extracting lower molecular weight polyphenols (Dai and Mumper 2010).

The total phenolic content of stevia leaf callus extract was estimated by Folin Ciocalteu's method using gallic acid as standard. The gallic acid standard solution was obtained by plotting the concentration versus the absorbance at $650 \mathrm{~nm}$ with a regression co-efficient $\left(R^{2}\right)=0.997$, with a linear equation standard of $y=0.007 x+0.049$. The milligram gallic acid equivalent (GAE) per gram of callus weight was derived from the regression line of $y=0.007 x+0.049$.

The total phenolic content of Stevia calli is presented in Table 5. Treatment combination of $1.5 \mathrm{mg} \mathrm{L}^{-1} 2,4-\mathrm{D}+2.0 \mathrm{mg} \mathrm{L}^{-1} \mathrm{BAP}\left(\mathrm{T}_{4}\right)$ exposed for $3 \mathrm{~h}$ yielded the highest phenolic content of $87.71 \mathrm{mg} \mathrm{g}^{-1}$ followed by $84.58 \mathrm{mg} \mathrm{g}^{-1}$ in $1.5 \mathrm{mg} \mathrm{L}^{-1} 2,4-\mathrm{D}+2.0 \mathrm{mg} \mathrm{L}^{-1}$ BAP $\left(\mathrm{T}_{4}\right)$ exposed for $5 \mathrm{~h}, 80.23 \mathrm{mg} \mathrm{g}^{-1}, 79.78 \mathrm{mg} \mathrm{g}^{-1}, 77.16 \mathrm{mg} \mathrm{g}^{-1}, 67.06 \mathrm{mg} \mathrm{g}^{-1}, 57.52 \mathrm{mg} \mathrm{g}$ ${ }^{1}$ and $54.83 \mathrm{mg} \mathrm{g}^{-1}$ respectively. However, it is also presented in Table 5 that during the 1h exposure of cultures inoculated in MS+1.5mg L-1 2,4-D + 2.0mg L-1 BAP $\left(T_{4}\right)$ and $5 \mathrm{~h}$ exposure of cultures inoculated in MS+1.5 $\mathrm{mg} \mathrm{L}^{-1} 2,4-\mathrm{D}+3.0 \mathrm{mg} \mathrm{L}^{-1} \mathrm{BAP}\left(\mathrm{T}_{5}\right)$ had sudden decrease in the phenolic content. It is interesting to note that the non-exposure of callus in MS+1.5mg L-1 2,4-D + 2.0 $\mathrm{mg} \mathrm{L}^{-1}$ BAP medium had slight increase of total phenolic content compared to the $1 \mathrm{~h}$ exposure. According to Nantitanon et al (2010) varying results of phenolic content could be due to several factors such as the UV exposure, environment and during the extraction done during the total phenolic determination assay.

The results obtained generally showed that both medium composition and time of exposure affected the production of phenolic content of Stevia leaf callus due to the in vitro stress condition of UV radiation experienced by leaf callus tissue. However, it was also observed that when stevia leaf callus tissue was exposed at longer time, it resulted to lesser total phenolic content compared to $3 \mathrm{~h}$ exposure. Similarly, Manaf et al (2016) study reported also that Echinacea purpurea callus culture exposed 
to UV-B light showed a significant increment in total phenols after $2 \mathrm{~h}$ exposure time followed by $6 \mathrm{~h}$. Similarly, the stevia cultures in this study were exposed to UV-B light with less than an hour of exposure time for comparison. This study supported the research of Abou-Arab and Abu-Salem (2010), on the comparison of total phenolic contents and total flavonoid content of stevia callus and leaf, and it was found out that there were higher phenolic compound and flavonoid yield from stevia callus (33.99 and $30.03 \mathrm{mg} \mathrm{g}^{-1}$ dry weight) than leaf (24.01 and $18.93 \mathrm{mg} \mathrm{g}^{-1}$ dry weight).

Table 5. Total phenolic content (mg GAE per g sample) of Stevia calli as influenced by different exposure time to UV radiation.

\begin{tabular}{ccc}
\hline Medium Combination & $\begin{array}{c}\text { Length of } \\
\text { Exposure }\end{array}$ & $\begin{array}{c}\text { Total Phenolic Content of Ste via } \\
\text { (mg GAE per g callus weight }\end{array}$ \\
\hline $\mathrm{MS}+1.5 \mathrm{mg} \mathrm{L}^{-1} 2,4-\mathrm{D}+2.0 \mathrm{mg} \mathrm{L}^{-1}$ BAP & Oh & $77.16^{\mathrm{e}} \pm 0.05$ \\
& $1 \mathrm{~h}$ & $54.83^{\mathrm{h}} \pm 0.02$ \\
$\mathrm{MS}+1.5 \mathrm{mgL}-12,4-\mathrm{D}+3.0 \mathrm{mg} \mathrm{L}^{-1} \mathrm{BAP}$ & $5 \mathrm{~h}$ & $87.72^{\mathrm{a}} \pm 0.01$ \\
& Oh & $84.58^{\mathrm{b}} \pm 0.021$ \\
& 1h & $57.52^{\mathrm{g}} \pm 0.01$ \\
& $3 \mathrm{~h}$ & $79.78^{\mathrm{d}} \pm 0.04$ \\
& $5 \mathrm{~h}$ & $80.23^{\mathrm{c}} \pm 0.04$ \\
& & $67.06^{\mathrm{f}} \pm 0.01$ \\
\hline
\end{tabular}

*Results presented as mean \pm standard deviation

*Means sharing a letter in the group label are not significantly different at the $5 \%$ level of significance.

Abiotic stress such as UV radiation exposure was reported to have a beneficial effect in production of secondary metabolites. Phenolic compounds are secondary metabolites that have been widely distributed in plants and are important constituents of human diet and also serve as defense mechanism against biotic and abiotic stresses (Bhattacharya et al 2010). Phenolic compounds as antioxidant have the ability to destroy free radicals due to its hydroxyl group (Pourreza 2013).

\section{CONCLUSION}

Stevia leaf explant was the suitable explants used for callus induction in stevia since it showed the earliest callus formation after 11 days of incubation. All treatment combination used successfully induced callus formation on both explants but MS + 1.5 $\mathrm{mg} \mathrm{L}^{-1} 2,4-\mathrm{D}+2.0 \mathrm{mg} \mathrm{L}^{-1} B A P\left(\mathrm{~T}_{4}\right)$ induced early callus induction in leaf explants of $95 \%$ and; $M S+1.0 \mathrm{mg} \mathrm{L}^{-1} 2,4-\mathrm{D}+4.0 \mathrm{mg} \mathrm{L}^{-1} \mathrm{BAP}\left(\mathrm{T}_{3}\right)$ for internode explants with $90 \%$ callus formation. From the result of total phenolic determination by Folin-Ciocalteu method, treatment combination of $\mathrm{MS}+1.5 \mathrm{mg} \mathrm{L}^{-1} 2,4-\mathrm{D}+2.0 \mathrm{mg} \mathrm{L}^{-1} \mathrm{BAP}\left(\mathrm{T}_{4}\right)$ with $3 \mathrm{~h}$ of exposure had the highest total phenolic content of stevia callus with $87.71 \mathrm{mg} \mathrm{g}^{-1}$ of callus weight. Hence, both the culture medium combination and the length of exposure to UV affect the production of phenolic content of stevia calli.

\section{RECOMMENDATION}

Further studies may be conducted on different levels of BAP and 2,4D at longer exposure to UV radiation. 


\section{REFERENCES}

Abou-Arab E and Abu-Salem FM. 2010. Evaluation of bioactive compounds of Stevia rebaudiana leaves and callus. African Journal of Food Science 4(10): 627634

Bhattacharya A, Sood P and Citovsky V. 2010. The roles of plant phenolics in defense and communication during Agrobacterium and Rhizobium infection. Molecular Plant Pathology 11(5):705-719

Cetin ES. 2014. Induction of secondary metabolite production by UV-C radiation in Vitis vinifera L. Öküzgözü callus cultures. Biological Research 47(1):37

Dai J and Mumper RJ. 2010. Plant phenolics: extraction, analysis and their antioxidant and anticancer properties. Molecules 15(10):7313-7352

Debnath M. 2008. Clonal propagation and antimicrobial activity of an endemic medicinal plant Stevia rebaudiana. Plant Biotechnology Laboratory, Department of Biotechnology, JECRC Foundation, Mahatma Gandhi Institute of Applied Sciences, Shri Ram Ki Nangal, Via Vatika, Tonk road, Jaipur, India 303905

Do QD, Angkawijaya AE, Tran-Nguyen PL, Huynh LH, Soetardjo FE, Ismadji S \& Ju YH. 2013. Effect of extraction solvent on total phenol content, total flavonoid content, and antioxidant activity of Limnophila aromatica. Journal of Food and Drug Analysis 22(3):296-302

Goyal S, Samsher K \& Goyal RK. 2010. Stevia (Stevia rebaudiana) a bio-sweetener: a review. International Journal of Food Sciences and Nutrition 61(1):1-10

Gupta E, Purwar S, Sandaram S \& Gai GK. 2013. Nutritional and therapeutic values of Stevia rebaudiana: a review. Journal of Medical Plants Research 7(46):33433353

Gupta P, Satyawati S \& Saxena S. 2010. Callusing in Stevia rebaudiana (Natural Sweetener) for steviol glycoside production. World Academy of Science, Engineering and Technology 48:572-576

Gurel S, Gurel E \& Kaya Z. 2001. Callus development and indirect shoot regeneration from seedling explants of sugarbeet (Beta Vulgaris) cultured in-vitro. Turkish Journal of Botany 25:25-33

Huang WY, Cai YZ \& Zhang Y. 2009. Natural phenolic compounds from medicinal herbs and dietary plants: potential use for cancer prevention. Nutrition and Cancer 62(1):1-20

Ikeuchi M, Sugimoto K \& Iwase A. 2013. Plant callus: mechanisms of induction and repression. The Plant Cell 25(9):3159-3173

Janarthanam B, Gopalakrishnan M, Sai GL \& Sekar T. 2009. Plant regeneration from leaf derived callus of Stevia rebaudiana Bertoni. Plant Tissue Culture \& Biotechnology 19(2):133-141

Jeyakumar $\mathrm{J}$ and Vivekanandan L. 2015. Optimization of conditions for callus induction and indirect organogenesis of Cucumis anguria L. Asian Journal of Plant Science and Research 5(11):53-61

Kaur C and Kapoor HC. 2002. Anti-oxidant activity and total phenolic content of some Asian vegetables. International Journal of Food Science and Technology 37(2):153-161

Manaf HH, Rabie KAE \& Abd El-Aal MS. 2016. Impact of UV-B radiation on some biochemical changes and growth parameters in Echinacea purpurea callus and suspension culture. Annals of Agricultural Sciences 61(2):207-216 
Murashige T and Skoog F. 1962. A revised medium for rapid growth and bio assays with tobacco tissue cultures. Physiologia Plantarium 15(3):473-497

Nantitanon W, Yotsawimonwat S \& Okonogi S. 2010. Factors influencing antioxidant activities and total phenolic content of guava leaf extract. LWT - Food Science and Technology 43(7):1095-1103

Naz S and Hashmi A. 2008. In vitro callogenesis and organogenesis in different explants of Stevia (Stevia rebaudiana). Pakistan Sugar Journal 24(2):20-31

Pawar SV, Khandagale VG, Jambhale VM, Jadhav AS \& Pawar BD. 2015. In vitro regeneration studies in stevia through nodal segment and shoot tip. The Bioscan 10(3):1007-1010

Pourreza N. 2013. Phenolic compounds as potential antioxidant. Jundishapur Journal of Natural Pharmaceutical Products 8(4):149-150

Raina R, Bhandari SK, Chand R \& Sharma Y. 2013. Strategies to improve poor seed germination in Stevia rebaudiana, a low calorie sweetener. Journal of Medicinal Plants Research 7(24):1793-1799

Sharma N, Gauchan DP, Dhakal A, Luite A, Shakyas S \& Shakyas R. 2015. Establishment of regenerative callus, cell suspension system and molecular characterization of Stevia Rebaudiana Bertoni for the production of Stevioside in In vitro. International Journal for Research in Applied Science \& Engineering Technology 3(8):133-144

Shukla S, Mehta A, Bajpai K \& Shukla S. 2009. In vitro antioxidant activity and total phenolic content of ethanolic leaf extract of Stevia rebaudiana Bert. Food and Chemical Toxicology 47(9):2338-2343 